Mortality was $22.5 \%$ (20/89 patients), Cl95 (14.3-32.5). Mean time from diagnosis to the event was 18 months. The primary cause of death was sepsis $14 / 20(70 \%)$. Conclusions: Mortality of patients with inflammatory myopathies was $22 \%$, and the primary cause was infectious. In the analysis of multiple variables, male sex, presence of neoplasms and serious infectious complications were significantly factors associated with mortality.

References:

[1] J Clin Rheumatol 2016; 22: 51-56.

[2] Med Clin 1999; 112:521-6.

Disclosure of Interest: None declared

DOI: 10.1136/annrheumdis-2017-eular.5243

\section{AB0607 PULMONARY EMBOLISM IN SYSTEMIC SCLEROSIS - ONE YEAR FOLLOW UP}

A.C. Duarte ${ }^{1}$, I. Cordeiro ${ }^{1}$, M. Ferreira ${ }^{2}$, T. Judas ${ }^{2}$, M.J. Loureiro ${ }^{3}$, J. Santos ${ }^{4}$ S. Carmona ${ }^{4}$, M.J. Santos ${ }^{1}$, A. Cordeiro ${ }^{1} \cdot{ }^{1}$ Rheumatology; ${ }^{2}$ Internal Medicine; ${ }^{3}$ Cardiology; ${ }^{4}$ Nuclear Medicine, Hospital Garcia de Orta, Almada, Portugal

Background: Risk of pulmonary embolism (PE) in systemic sclerosis (SSc) has been estimated between 2.51-3.47 fold higher when compared to nonSSc patients (pts). Proinflammatory state, vasculopathy and vascular injury may contribute to a prothrombotic state in SSc and increased risk for venous thromboembolism.

Objectives: Calculate frequency and identify possible risk factors for PE among SSc pts;analyse efficacy of longterm anticoagulation (ACO) in these pts.

Methods: We conducted a retrospective analysis of 110 pts with SSc followed in our Rheumatology department and selected those who performed lung ventilation/perfusion scintigraphy (V/Q scan) or $\mathrm{CT}$ pulmonary angiography due to worsening dyspnea/fatigue or isolated reduction of the carbon monoxide diffusing capacity (DLCO). We collected demographic features, comorbidities, age at SSc diagnosis, anti-nuclear antibody specificities, dyspnea according to New York Heart Association (NYHA) classes and results of cardiopulmonary exams. PE and related variables were assessed at baseline and after 12 months of ACO. Results: PE was diagnosed in 12 out of 29 (41.4\%) SSc pts that met inclusion criteria, with the majority presenting bilateral peripheral multisegmental defects. Most were females $(91.7 \%)$, mean age of $59.4( \pm 12.7)$ years (yrs). Two thirds were diagnosed with limited SSc with mean disease duration of $13.3( \pm 12.9)$ yrs. Mean time between SSc and PE diagnosis was $8.5 \pm 8.2 \mathrm{yrs}$, although one third of the pts was diagnosed within the first year of SSc diagnosis. One patient was taking oral contraceptives and none had thrombophilia, previous surgery or cancer.

One third was classified as having NYHA class $\geq 3$, with a mean N-terminal pro-brain natriuretic peptide (NTproBNP) of $1108 \mathrm{pg} / \mathrm{mL}$ (19 to 8069 ). Six pts had concomitant interstitial lung disease (ILD) and 8 had an estimated pulmonary artery systolic pressure (PASP) $\geq 35 \mathrm{mmHg}$ ( 6 of them had concomitant ILD). From these only 2 had pulmonary hypertension confirmed by right heart catheterization and 1 died.

When comparing SSc pts with and without PE, Scl70 positivity was more common in pts with $P E(p=0.041)$. No significant associations were found between PE and several cardiovascular risk factors.

From the 12 pts with PE, 10 were on longterm ACO:5 on rivaroxaban, 4 on warfarin and 1 on apixaban. Clinical reassessment after 12 months of ACO is shown in figure 1.

\begin{tabular}{|c|c|c|c|c|c|c|}
\hline Patient & Anticoagulant & Symptoms* & NT-pro BNP & V/Q scan & $\begin{array}{c}\text { PASP } \\
(\mathrm{mmHg})\end{array}$ & DLCO \\
\hline 1 & Warfarin & $\begin{array}{c}\text { Discrete } \\
\text { improvement }\end{array}$ & $\begin{array}{c}\text { Reduction } \\
(>100 \mathrm{pg} / \mathrm{mL})\end{array}$ & Not available & Not available & Identic \\
\hline 2 & Rivaroxaban & Identic & Identic & Identic & Identic & Identic \\
\hline 3 & Non-pplicables & & & & & \\
\hline 4 & Rivaroxaban & \multicolumn{5}{|c|}{ anticongulated for $<6$ months } \\
\hline 5 & Warfarin & Identic & Identic & Identic & Identic & $\begin{array}{c}\text { Discrete } \\
\text { improvement } \\
(29 * 36)\end{array}$ \\
\hline 6 & Apixaban & $\begin{array}{c}\text { Discrete } \\
\text { improvement }\end{array}$ & $\begin{array}{c}\text { Discrete } \\
\text { raise }( \pm 100 \\
\mathrm{pg} / \mathrm{mL})\end{array}$ & $\begin{array}{l}\text { Decrease in } \\
\text { perfusion } \\
\text { defects }\end{array}$ & $\begin{array}{c}\text { Worsening } \\
(28=40)^{x}\end{array}$ & Identic \\
\hline 7 & Warfarin & \begin{tabular}{c|} 
Discrete \\
improvement
\end{tabular} & Identic & Identic & $\begin{array}{c}\text { Improvement } \\
(51 \approx 30)\end{array}$ & Not available \\
\hline 8 & Warfarin & Identic & $\begin{array}{c}\text { Marked raise } \\
(>5000 \\
\mathrm{pg} / \mathrm{mL})^{x}\end{array}$ & Not available & Not avoilable & Not available \\
\hline 9 & Non-pplicables & & & & & \\
\hline 10 & Rivaroxaban & Identic & $\begin{array}{c}\text { Raise }( \pm 200 \\
\mathrm{pg} / \mathrm{mL})\end{array}$ & Identic & Not available & Identic \\
\hline 11 & Rivaroxaban & $\begin{array}{c}\text { Discrete } \\
\text { improvement }\end{array}$ & Identic & Identic & Not avallable & Not available \\
\hline 12 & Rivaroxaban & & ontice & gulated for $<6$ & ronths & \\
\hline
\end{tabular}

Conclusions: Our results suggest that PE is frequent in SSc and must be considered in the differential diagnosis of worsening fatigue and dyspnea and/or reduction of DLCO/PASP increase. PE may occur more frequently in Scl70 positive pts and early in disease course, probably due to vasculopathy and vascular injury being more prominent in the early phase of the disease. Although there is no consensus regarding the optimal ACO, the disease's vasculopathy seems to be an important contributor, potentially preventing improvement in perfusion defects, regardless of the anticoagulant used.

Disclosure of Interest: None declared

DOI: 10.1136/annrheumdis-2017-eular.5214

\section{AB0608 PREDICTIVE FACTORS FOR LONG-TERM SURVIVAL AND DISEASE PROGRESSION OF SYSTEMIC SCLEROSIS - A LONGITUDINAL ANALYSIS}

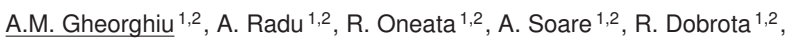
S. Magda ${ }^{2,3}$, T. Constantinescu ${ }^{2,4}$, R. Jurcut ${ }^{2,5}$, R. Sfrenţ-Cornăţeanu ${ }^{2,6}$, M. Bojincă ${ }^{1,2}$, V. Stoica ${ }^{1,2}$, C. Mihai ${ }^{1,2}{ }^{1}$ Internal Medicine and Rheumatology, Cantacuzino Hospital; ${ }^{2}$ Carol Davila University of Medicine and Pharmacy;

${ }^{3}$ Emergency University Hospital; ${ }^{4}$ Marius Nasta Institute of Pneumology; ${ }^{5}$ C.C. Iliescu Institute for Cardiovascular Diseases; ${ }^{6}$ Physiopathology and Immunology Department, Bucharest, Romania

Background: Systemic sclerosis (ScS) has unpredictable course and high mortality. Generalised Estimating Equations (GEE) is a technique useful for longitudinal data analysis, using data from all time points and adjusting for within-patient correlation,i.e. correlation between time points within the same patient. GEE does not require a normal distribution of dependent variables, making it attractive for analyzing SSc data.

Objectives: To identify predictive factors for death and unfavorable outcomes. Methods: Data of SSc patients with $\geq 2$ visits in our EUSTAR centre in 2004-2016 were analyzed. GEE investigated the relationship over time between outcomes (death, digital ulcers (DUs), forced vital capacity (FVC), modified Rodnan skin score (mRSS)) and potential predictors (age, gender, disease duration, cutaneous subset, mRSS at baseline, DUs history, DLCO, left ventricle ejection fraction (LVEF), proteinuria), separately for each predictor and in combined models.

Results: 89 patients $(12.4 \%$ males, mean \pm SD age $49.2 \pm 12.2$ years, disease duration $4.1 \pm 7.5$ years) were included, with a follow-up of up to 13years. There were 14deaths, most due to lung involvement (7/14). In multivariable GEE analysis (Table 1), predictors of death were a shorter disease duration, DUs history, and a lower LVEF. Predictors for FVC decrease over time were difuse cutaneous subset (dcSSc), younger age and lower DLCO. Younger age, shorter disease duration and higher baseline mRSS were the most important predictors for higher mRSS at follow-up. The only predictor for the development of new DUs was a history of DUs.

Table 1. Prediction factors for death and for evolution over time of parameters reflecting disease severity in SSc

\begin{tabular}{lcccc}
\hline Predictors & Death & DUs & FVC & mRSS \\
\hline & OR $(95 \% \mathrm{Cl})$ & $\mathrm{OR}(95 \% \mathrm{Cl})$ & $\mathrm{B}(95 \% \mathrm{Cl})$ & $\mathrm{B}(95 \% \mathrm{Cl})$ \\
Age & $1.1(0.9,1.3)$ & $0.9(0.9,1.0)$ & $0.3(0.1,0.6)^{\star}$ & $-0.1(-0.2,-0.01)^{\star}$ \\
Disease duration & $0.8(0.7,0.9)^{\star \star \star}$ & $1.0(0.9,1.1)$ & $-0.0(-0.3,0.3)$ & $-0.1(-0.3,-0.03)^{\star \star}$ \\
mRSS baseline & $0.9(0.9,1.1)$ & $1.1(0.9,1.1)$ & $0.2(-0.2,0.7)$ & $0.4(0.3,0.6)^{\star \star \star}$ \\
DLCO & $0.9(0.9,1.0)$ & $1.0(0.9,1.0)$ & $0.5(0.3,0.6)^{\star \star \star}$ & $0.1(-0.0,0.0)$ \\
LVEF & $0.9(0.90,0.98)^{\star \star}$ & $0.9(0.9,1.1)$ & $0.2(-0.2,0.7)$ & $0.0(-0.2,0.2)$ \\
Male gender & $1.9(0.3,11.2)$ & $0.5(0.1,1.9)$ & $0.7(-9.3,10.7)$ & $-1.2(-3.9,1.5)$ \\
dcSSc & $6.8(0.6,81.7)$ & $0.7(0.2,2.9)$ & $-16.5(-28.9,-4.9)^{\star \star}$ & $1.7(-0.1,3.4)$ \\
DUs history & $13.1(3.1,55.8)^{\star \star \star}$ & $28.4(2.3,356.4)^{\star \star}$ & $3.2(-2.1,8.4)$ & $0.2(-1.4,1.7)$ \\
Proteinuria & $1.1(0.6,1.8)$ & $0.9(0.4,1.9)$ & $2.2(-2.5,6.8)$ & $1.7(-0.1,3.5)$ \\
\hline
\end{tabular}

${ }^{\star} \mathrm{p}<0.05,{ }^{\star \star} \mathrm{p}<0.01,{ }^{* \star \star} \mathrm{p}<0.001$.

Conclusions: Patients with shorter disease duration, dcSSc, higher mRSS, lower DLCO and LVEF and a history of DUs had a more unfavorable course. GEE is a robust technique for longitudinal data analysis, excellent for identifying prediction factors in SSc.

Acknowledgements: This abstract is part of the QUANTICAP project, UEFIS-CDI PN-II- PT-PCCA-2013-4-1589 grant.

Disclosure of Interest: None declared

DOI: 10.1136/annrheumdis-2017-eular.5783

\section{AB0609 CORRELATION OF PSYCHOLOGICAL PROFILE (MMPI-II A BDII TESTS) OF SCLERODERMA PATIENTS WITH ORGAN MANIFESTATION AND IMMUNOLOGICAL PROFILE}

A. Smržová ${ }^{1}$, L. Hubáčková ${ }^{2}$, S. Kreiselová ${ }^{2}$, J. Zapletalová ${ }^{3}$, P. Horák ${ }^{4} .{ }^{1} 3 R d$ Department of Internal Medicine - Nephrology, Rheumatology and Endocrinology; ${ }^{2}$ Department of Psychology; ${ }^{3}$ Department of Medical Biophysics: ${ }^{4}$ Faculty of Medicine and Dentistry, Palacký University Olomouc, Olomouc, Czech Republic

Background: There is high prevalence of mood disorders in patients with systemic scleroderma. Psychical distress can influent some of clinical manifestations and can worse the course of the disease and socioeconomicall status of patients.

Objectives: The aim of study is detection of correlations of depression and psychological profile measures by MMPI-II (The Minnesota Multiphasic Personality Inventory) and BDI-II (The Beck Depression Inventory-II) and organ manifestation and immunological profile of patients with systemic sclerosis. 